\title{
The Climate in the European Union and the Enlarged European Region is a Determinant of the COVID-19 Case Fatality Ratio
}

\author{
Germano Orrù ${ }^{1(\mathbb{D})}$, Ferdinando Romano ${ }^{2(\mathbb{D})}$, Alessandra Scano ${ }^{1(\mathbb{D})}$, Angelo Restivo ${ }^{3 \mathbb{D}}$, Stefano Del

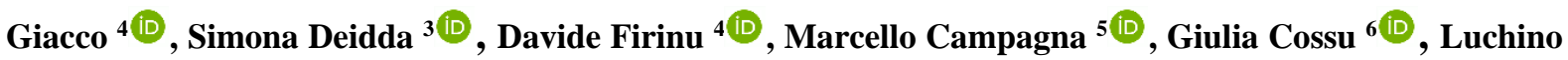 \\ Chessa $^{7 \text { (D) }}$, Goce Kalcev ${ }^{8}$ (D), Mauro Giovanni Carta ${ }^{6}$ (D)
}

1 Department of Surgical Sciences, University of Cagliari, Italy; gerorru@gmail.com (G.O.), alessandrascano@libero.it (A.S.);

2 University La Sapienza, Rome, Italy; ferdinando.romano@uniroma1.it (F.R.);

3 Colorectal Surgery Unit, Department of Surgical Science, University of Cagliari, Italy; arestivo@unica.it (A.R.), simonadeidda86@gmail.com (S.D.);

4 Internal Medicine, Allergy and Clinical Immunology, Department of Medical Sciences, University of Cagliari, Italy; delgiac@gmail.com (S.D.G), davide.firinu@unica.it (D.F.);

5 Occupational Health Section, Department of Medical Sciences and Public Health, University of Cagliari, Italy; mcampagna@unica.it (M.C.);

6 Department of Medical Sciences and Public Health, University of Cagliari, Italy; giuliaci@icloud.com (G.C.), mgcarta@tiscali.it (M.G.K.);

7 Center for the Study of Liver Diseases, Department of Medical Sciences, University of Cagliari, Italy; luchinochessa@unica.it (L.C.);

8 International PhD in Innovation Sciences and Technologies, University of Cagliari, Italy; gocekalcev@ yahoo.com (G.K.);

* Correspondence: gocekalcev@yahoo.com;

Received: 1.10.2020; Revised: 8.11.2020; Accepted: 12.11.2020; Published: 15.11.2020

\begin{abstract}
Climate could influence the COVID-19 pandemic, but while no evidence has been advanced on the influence of colder climates, some studies have provided data to support a possible heat-related protective factor. The objective is to verify whether areas with a Cold Temperate Climate (TC) have a higher Case Fatality Ratio (CFR) for COVID-19 than areas with a Cold Climate (CC) or with a Mediterranean Climate (MC) in the European Union and the Enlarged European Region. Countries or regions were subdivided into 3 groups according to the Köppen climate classification system: TC (Cfa, $\mathrm{Cfb}$ and $\mathrm{Cfc}$ in the Köppen system); MC (Csa, Csb); CC (D and E in the Köppen system). The total number of cases and the total number of deaths were detected on 13 August 2020 on the COVID-19 Map - Johns Hopkins Coronavirus Resource Center-the CFR was thus calculated by area. Living in TC areas is strongly associated with risk of a high Case Fatality Ratio for COVID-19, OR for MC $=0.42$, IC 95\% 0.41-0.43; OR for $\mathrm{CC}=0.33$, IC 95\% 0.33-0.35. The results are confirmed in the EU, OR per $\mathrm{MC}=0.85$, CI 95\% 0.84-0.87; OR per CC=0.63, IC 95\% 0.61-0.65. The study found that the IC in a humid temperate climate is associated with higher CFR with respect to the coldest and warmest temperate climates in Europe. This does not appear to be the only determinant of the pandemic.
\end{abstract}

Keywords: climate; COVID-19; CFR; enlarged EU; pandemic.

(c) 2020 by the authors. This article is an open-access article distributed under the terms and conditions of the Creative Commons Attribution (CC BY) license (https://creativecommons.org/licenses/by/4.0/).

\section{Introduction}

It has been hypothesized that the climate could influence the progress of the COVID19 pandemic. In particular, it has been assumed that the coldest and hottest climates can counter the pandemic. However, apart from some anecdotal considerations [1], no evidence has been 
advanced on the influence of colder climates. Studies on the influence of warmer climates have been restricted to analyses relating to changes within single nations [2] and therefore lacking situations of high variability that could confirm the factor independently of specific confounding factors. It has also been found that the lethality of the virus was lower in equatorial areas than in the rest of the world [3], even though in this case, one must consider that fact that there are few equatorial nations and their COVID-19 incidence rate is quite different (countries with no cases are almost all equatorial but they are also isolated islands). The trend in a few nations with high incidence (i.e., Singapore) may have influenced the overall results of the study. Therefore, it is difficult to extend the result to other situations that present extremely high variability for this parameter in countries with similar weather. It is well known that a comparison of the incidence of COVID cases in different countries poses numerous difficulties that are not easily overcome. The number of known cases in a given country could, in fact, be biased by several factors such as (1) accessibility to tests in its health system, (2) reliability of data transmitted to institutional research bodies and international health organizations (with or without intentional manipulation), (3) the country's demographic profile with more or less extension of ages at risk. A somewhat more reliable factor in assessing virus activity could be the assessment of the Case-Fatality Ratio in different areas. The case Case-Fatality Ratio of COVID is the proportion of deaths from COVID in a given country or area divided by the total amount of people diagnosed with COVID in this country/area in a given period [4]. The CaseFatality Ratio (CFR) is not directly related to accuracy in identifying cases; in fact, it is based on the cases already identified. It is independent of the incidence rate of the disease in a given population. It may be less biased by errors in communication and a desire to hide the pandemic's extent because death is counted as declared cases, which are thus somewhat more difficult to conceal. However, the Case-Fatality Ratio can be influenced, albeit indirectly, by the efficiency of the health system because the many diagnostic tests conducted in a particular country could lead to the identification of a greater share of mild cases, which could lower the rate, widening the denominator, regardless of the aggressiveness of the virus. However, this possible bias may be partially disputed if a possible climate-related trend was confirmed in nations with comparable health systems.

The objective of this study is to verify whether areas with a Cold Temperate climate have a higher Case Fatality Ratio for COVID-19 than areas with a cold climate (therefore colder on average) or with a Mediterranean climate (therefore warmer on average) in the European Union and the Enlarged European Region. The specific analysis of the European Union allows the hypothesis to be verified in a context of states with comparable national health systems, while the enlarged European Region allows the hypothesis to be verified in a broader context, which is, therefore, less affected by other possible confounding variables.

\section{Materials and Methods}

The subdivision of the European Union's climatic regions and the enlarged European area was carried out according to Chen's classification (2020), which was based on the original scheme by Köppen (1936). Peri-European desert areas were excluded [5, 6]. The regions were divided into 3 groups: Humid Temperate (corresponding to the $\mathrm{Cfa}, \mathrm{Cfb}$, and $\mathrm{Cfc}$ areas of the Köppen classification); Mediterranean (Csa, Csb areas of the Köppen classification); Cold (areas D and E of the Köppen classification). The total number of cases was detected on 13 August 2020 on the COVID-19 Map-Johns Hopkins Coronavirus Resource Center (detected 2020). The total number of deaths was thus calculated as the Case-Fatality Ratio for the 
countries with different climatic areas (Italy and Spain). Although France has only one Region (Midi-Provence-Côte d'Azur) belonging to the Mediterranean area, it was not possible to calculate the differentiated data because no data was provided. The role of climatic zones as a possible determinant was calculated in terms of odds ratio; the $95 \%$ confidence limits were calculated using the simplified Miettinen method. A hot, humid climate was considered as a pivot for the other two climates. The comparison with cold climate countries was conducted with and without Russia; in fact, the frequency of cases in this single state is many times greater than that of all the others belonging to the same climate group. Suppose the results of the two evaluations did not agree. In that case, one could, therefore, hypothesize the presence of a specific factor independent of the climate.

\section{Results and Discussion}

Table 1 shows the European Union regions/countries and of the enlarged European area divided by Humid Temperate (1a), Mediterranean $(1, \mathrm{~b})$, and Cold climate. For each nation or Region (in nations with different climate regions such as Spain and Italy), the number of cumulative cases and the number of global deaths for COVID are reported as recorded on 13 August 2020 on the COVID-19 Map - Johns Hopkins Coronavirus Resource Center [7]. The Case-Fatality Ratio obtained by accumulating the data in tables in the different areas is as follows: for the regions with a humid climate, $9.92 \%$ in the enlarged European area and $9.90 \%$ in the European Union; for regions with a Mediterranean climate, $4.89 \%$ in the enlarged European area and $4.43 \%$ in the European Union; for regions with a Mediterranean climate, $2.25 \%$ (3.60\% without Russia) in the enlarged European area and $5.87 \%$ in the European Union.

Table 1 a. Case Fatality Ratio in the European Union and enlarged European Regions with humid temperate

\begin{tabular}{|c|c|c|c|}
\hline Region /Country & $\begin{array}{l}\text { weathe } \\
\text { Total Cases }\end{array}$ & $\begin{array}{c}\text { Global } \\
\text { Deaths on } 13 \text { August } 2020 \\
\end{array}$ & $\begin{array}{c}\text { Case Fatality } \\
\text { Ratio } \\
\end{array}$ \\
\hline Abruzzo EU & 3,516 & 472 & \\
\hline Marche EU & 6,976 & 987 & \\
\hline Emilia Romagna EU & 30,220 & 4,298 & \\
\hline Umbria EU & 1,517 & 80 & \\
\hline Toscana EU & 10,707 & 1,137 & \\
\hline Piedmont EU & 31,956 & 4,138 & \\
\hline Valle d'Aosta EU & 1,217 & 146 & \\
\hline Lombardy EU & 97,054 & 16,833 & \\
\hline Veneto EU & 20,801 & 2,092 & \\
\hline PA Bolzano EU & 2,779 & 292 & \\
\hline PA Trento EU & 4,998 & 405 & \\
\hline Friuli VG EU & 3,461 & 348 & \\
\hline Catalonia EU & 89,909 & 5,706 & \\
\hline Aragon EU & 19,418 & 991 & \\
\hline Navarra EU & 7,713 & 531 & \\
\hline La Rioja EU & 4,333 & 366 & \\
\hline Pays Vasco EU & 19,009 & 1,553 & \\
\hline Cantabria EU & 2,824 & 220 & \\
\hline Asturias EU & 2,733 & 334 & \\
\hline France ( Provence Not Available) EU & 230,874 & 30,247 & \\
\hline Belgium EU & 75,647 & 9,900 & \\
\hline The Netherlands EU & 61,118 & 6,182 & \\
\hline Luxemburg EU & 7,300 & 122 & \\
\hline Germany EU & 220,859 & 9,213 & \\
\hline Poland EU & 53,676 & 1,830 & \\
\hline Slovakia EU & 2,690 & 31 & \\
\hline Czechia UE & 19,075 & 391 & \\
\hline Hungary UE & 4,768 & 605 & \\
\hline
\end{tabular}


https://doi.org/10.33263/BRIAC113.1097910986

\begin{tabular}{l|c|c|c} 
Region /Country & Total Cases & $\begin{array}{c}\text { Global } \\
\text { Deaths on 13 August 2020 }\end{array}$ & $\begin{array}{c}\text { Case Fatality } \\
\text { Ratio }\end{array}$ \\
\hline Romania UE & 65,177 & 2,807 & \\
\hline Bulgaria UE & 13,893 & 342 & \\
\hline Ireland EU & 26,838 & 1,174 & \\
\hline Slovenia EU & 3,641 & 348 & \\
\hline Denmark EU & 15,070 & 621 & \\
\hline N. Macedonia & 12,217 & 530 & \\
\hline Montenegro & 3,813 & 73 & \\
\hline Serbia & 28,751 & 658 & \\
\hline Bosnia Herzegovina & 14,691 & 553 & \\
\hline Kosovo & 10,419 & 341 & \\
\hline United Kingdom & 315,581 & 46,791 & $9.02 \%$ \\
\hline San Marino & 669 & 42 & $9.92 \%$
\end{tabular}

Table 1 b. Case Fatality Ratio in the European and Peri-European Regions with Mediterranean Weather.

\begin{tabular}{|c|c|c|c|}
\hline Region /Country & Total Cases & $\begin{array}{c}\text { Global } \\
\text { Deaths on } 13 \text { August } 2020\end{array}$ & $\begin{array}{c}\text { Case Fatality } \\
\text { Ratio }\end{array}$ \\
\hline Sardinia EU & 1,462 & 134 & \\
\hline Sicily EU & 3,603 & 284 & \\
\hline Molise EU & 479 & 23 & \\
\hline Basilicata EU & 477 & 28 & \\
\hline Puglia EU & 4,793 & 554 & \\
\hline Calabria EU & 1,304 & 97 & \\
\hline Campania EU & 5,143 & 440 & \\
\hline Liguria EU & 10,330 & 1,569 & \\
\hline Lazio EU & 8,920 & 868 & \\
\hline Portugal EU & 53,223 & 1,764 & \\
\hline Galicia EU & 10,480 & 662 & \\
\hline Castilian y Leon EU & 22,169 & 284 & \\
\hline Madrid EU & 83,606 & 8,464 & \\
\hline Castilla La Mancha EU & 19,582 & 3,037 & \\
\hline Valencian Community EU & 15,934 & 1,442 & \\
\hline Murcia EU & 3,116 & 149 & \\
\hline Andalusia EU & 18,059 & 1,443 & \\
\hline Estremadura+ EU & 3,664 & 522 & \\
\hline Ceuta y Melilla EU & 348 & 2 & \\
\hline The Canaries EU & 3,167 & 164 & \\
\hline The Balearics EU & 3,780 & 225 & \\
\hline Greece EU & 6,177 & 216 & \\
\hline Cyprus EU & 1,291 & 20 & \\
\hline Malta EU & 1,190 & 9 & \\
\hline Croatia EU & 5,870 & 170 & \\
\hline Gibraltar & 203 & 0 & \\
\hline Israel & 88,151 & 639 & \\
\hline Lebanon & 7,413 & 89 & \\
\hline Turkey & 240,392 & 5,891 & \\
\hline Albania & 6,817 & 208 & \\
\hline Tunisia & 1,780 & 52 & \\
\hline Algeria & 36,699 & 1,333 & \\
\hline Morocco & 36,694 & 556 & \\
\hline Vatican City & 12 & 0 & \\
\hline Monaco & 141 & 4 & \\
\hline Total (only) EU & 288,167 & 22,570 & $7.80 \%$ \\
\hline Total & 706,469 & 31,342 & $4.43 \%$ \\
\hline
\end{tabular}

Table 1 c. Case Fatality Ratio in the European and Peri-European Regions with cold weather.

\begin{tabular}{l|c|c|c} 
Region /Country & Total Cases & $\begin{array}{c}\text { Global } \\
\text { Deaths on 13 August 2020 }\end{array}$ & \\
\hline Austria EU & & 724 & \\
\hline Finland EU & 22,439 & 333 & \\
\hline Estonia EU & 7,642 & 63 & \\
\hline Latvia EU & 2,164 & 32 & \\
\hline Lithuania EU & 1,303 & 81 &
\end{tabular}




\begin{tabular}{l|c|c|c} 
Region /Country & Total Cases & $\begin{array}{c}\text { Global } \\
\text { Deaths on 13 August 2020 }\end{array}$ & Case Fatality Ratio \\
\hline Sweden EU & & 5,774 & \\
\hline Switzerland & 83,455 & 1,991 & \\
\hline Liechtenstein & 37,169 & 1 & \\
\hline Moldavia & 90 & 863 & \\
\hline Ukraine & 28,697 & 1,999 & \\
\hline Belarus & 86,504 & 595 & \\
\hline Russia & 69,102 & 15,531 & \\
\hline Norway & 900,745 & 256 & \\
\hline Iceland & 9,783 & 10 & \\
\hline Faroe Islands & 1972 & 0 & $5.87 \%$ \\
\hline Greenland & 339 & 0 & $3.25 \%$ \\
\hline Total only EU & 14 & 7,007 & \\
\hline Total & 119,312 & 28,253 & \\
\hline Total without Russia & $1,253,727$ & 12.722 &
\end{tabular}

Table 2 compares these differences and measures the Association between High Case Fatality Ratio and Humid Temperate Weather in the enlarged European Zone. Living in Humid Temperate Weather regions or countries is strongly associated with a risk of High Case Fatality Ratio for COVID-19, with regard to both inhabitants of the warmest Mediterranean zones $(\mathrm{OR}=0.42$, IC 95\% 0.41-0.43) or those living in a cold climate zone $(\mathrm{OR}=0.33$, IC-95\% 0.33 0.35 and $\mathrm{OR}=0.20$, IC 95\% 0.20-0.21 when Russia is excluded).

Table 2. Association between high case fatality ratio and humid temperate weather in the enlarged European Zone.

\begin{tabular}{l|c|c|c|c|c} 
Weather Zone & $\begin{array}{c}\text { Cumulative } \\
\text { cases }\end{array}$ & Survivors & Global deaths & X2;p & $\begin{array}{c}\text { Ro, } \\
\text { CI 95\% }\end{array}$ \\
\hline $\begin{array}{l}\text { Humid Temperate } \\
\text { Weather }\end{array}$ & $1,548,885$ & $1,395,102$ & 153,783 & $==$ & $==$ \\
\hline $\begin{array}{l}\text { Mediterranean } \\
\text { Weather }\end{array}$ & 706,469 & 675,127 & 31,342 & $19,423.8$ & $0.42 ;$ \\
\hline Cold Weather & 352,982 & 340,260 & 12722 & 14394.07 & 0.33 \\
\hline $\begin{array}{l}\text { Cold Weather with } \\
\text { Russia }\end{array}$ & $1,253,727$ & $1,225,474$ & 28,253 & $\begin{array}{c}602004.7 \\
\mathrm{p}<0.00001\end{array}$ & $0.20-0.21$ \\
\end{tabular}

Table 3 compares the same differences and measures the Association between High Case Fatality Ratio and Humid Temperate Weather in the European Union. Living in Humid Temperate Weather regions or countries is confirmed as being associated with the risk of a High Case Fatality Ratio for Covid-19, with respect to both inhabitants of the warmest Mediterranean zones $(\mathrm{OR}=0.85$, IC 95\% 0.84-0.87) or those living in cold climate zone $(\mathrm{OR}=0.63$, IC $95 \%$ 0.61-0.65).

Table 3. Association between high case fatality ratio and humid temperate weather in the European Union.

\begin{tabular}{l|l|l|l|l|l} 
Weather Zone & Weather Zone & Cumulative cases & Survivors & Global deaths & X2; \\
\hline $\begin{array}{l}\text { Humid Temperate } \\
\text { Weather }\end{array}$ & $1,161,767$ & $1,057,022$ & 104,742 & $===$ & $==$ \\
\hline $\begin{array}{l}\text { Mediterranean } \\
\text { Weather }\end{array}$ & 288,167 & 265,297 & 22,570 & 387.83 & 0.85 \\
\hline $\begin{array}{l}\text { Cold Weather } \\
\text { (119,312 }\end{array}$ & 112,305 & 7,007 & $1342.36 \mathrm{p}<0.00001$ & $0.84-0.87$ \\
\hline
\end{tabular}

\subsection{Discussion.}

Ours is the first work that has found a humid temperate climate associated with a higher Case Fatality Ratio with respect to the coldest and warmest temperate climates. This was found both in the enlarged European area and by restricting the number of states/regions considered in the European Union alone. The first evaluation has the advantage of comparing a multiplicity 
of different conditions in terms of culture and other possible confounding factors (pollution, greater exposure to travelers, state of health, variables related to the quality of the health system in detecting and transmitting data) [16]; the second evaluation concerns a small number of states with more homogeneous conditions [17]. The fact that both evaluations' results are in agreement, therefore, reinforces the validity of the result. To our knowledge, there are no systematic studies in the literature on possible protection from the risk of mortality associated with cold climates in the Covid pandemic [ 18,19,20]. Some studies had found a possible protective effect related to heat; in fact, the equatorial countries showed a lower mortality rate out of the total of infected people than the remaining regions and territories located in nontemperate areas of three European nations (France, The Netherlands, and the United Kingdom) had a lower rate of lethality than metropolitan areas in the same nations, in partial independence of age distribution [8, 14]. Moreover, the provinces of 4 Italian regions with the highest temperature in March presented a lower mortality rate from COVID than the other provinces in the same 4 regions [9].

Furthermore, a negative linear relationship was found in Brazil between temperatures and the number of confirmed cases with a curve that flattened at a threshold of $25.8^{\circ} \mathrm{C}[2,13$, 21]. However, our data only concern the risk of mortality amongst cases and not the risk of disease. Furthermore, in Brazil, there was no data relating to a cold climate. Let's carefully analyze the data in our study. We find that although a humid temperate climate is associated with a high Case Fatality Ratio, other factors are undoubtedly significant. This emerges from the analysis of the states/regions that are strongly discordant from the weather-related trend. Among the nations with a humid temperate climate, for example, the high Case Fatality Ratio of the United Kingdom stands out (14.80 vs 9.92\%). Among the cold climate states, there is the case of Sweden (6.9 vs $2.25 \%$ ). Both nations implemented very limited and delayed lockdown measures.

A similar trend is not observed in Belarus, another country with limited lockdown. However, the data may not be comparable in this case [10]. Some areas with a high metropolitan density show higher CFR trends, for example, the Madrid area. This is possible in relation to greater exposure to the infection, given the greater difficulty of social distancing. Although this trend can be found in several areas with high urban density, it is not always present (for example, in Luxembourg) because probably other factors also come into play. It can also be noted that temperate regions close to the endemic explosion (such as Liguria) still have very high CFRs. This multiplicity of factors at play also highlights this study's limits; in fact, the current state of knowledge makes it impossible to balance the various potential confounding factors. Another limitation derives from the fact that a country provides the data on the pandemic or at the most by Region, while obviously, the climate does not respond to these limitations. For example, Catalonia has been placed among the humid temperate climates because most of its territory, but not all, have this type of climate. However, the same Region reports an intermediate Case Fatality Ratio (6.9\%) compared to those of the two climatic areas even in the European Union, and location in one or the other does not change the results. These considerations cannot be made for France's southern Region (with a Mediterranean climate) for which no data are available. Suppose our hypothesis has confirmed the interruption of the lockdown in Southern Europe. In that case, it could be followed, with the return of the cold by very problematic autumn $[11,12]$. It should also be noted that the second wave in Europe at the end of the summer was characterized by the interest above all of the young people due to the lack of respect for distances in discos and entertainment venues. Therefore, the spread of 
the epidemic to weaker bands could coincide with the increase in cold weather, and two risk elements would add up [1, 15, 22].

\section{Conclusions}

The study found that a humid temperate climate is associated with a higher Case Fatality Ratio concerning the coldest and warmest temperate climates in Europe. Although this does not appear to be the only determinant of the pandemic, it is an element that must be taken into serious consideration for the planning of response strategies.

\section{Funding}

This research received no external funding.

\section{Acknowledgments}

Goce Kalcev (MD) participated in the writing of this paper in the framework of the International Ph.D. in Innovation Sciences and Technologies at the University of Cagliari, Italy.

\section{Conflicts of Interest}

The authors declare no conflict of interest.

\section{References}

1. Carta, M.G.; Scano, A.; Lindert, J.; Bonanno, S.; Rinaldi, L.; Fais, S.; Orrù, G. Association between the spread of COVID-19 and weather-climatic parameters. Eur Rev Med Pharmacol Sci 2020, 24, 8226-8231, https://doi.org/10.26355/eurrev_202008_22512.

2. Prata, D.N.; Rodrigues, W.; Bermejo, P.H. Temperature significantly changes COVID-19 transmission in (sub)tropical cities of Brazil. Science of The Total Environment 2020, 729, https://doi.org/10.1016/j.scitotenv.2020.138862.

3. Carta, M.G.; Orrù, G.; Scano, A.; Coghe, F.; Nunnari, G.; Facchini, G.; Numis, F.G.; Berretta, M. In the face of the SARS-CoV-2 outbreak, do people suffering from oncological disease need specific attention? Eur Rev Med Pharmacol Sci 2020, 24, 3434-3436, https://doi.org/10.26355/eurrev_202004_20794.

4. Last, J.M. Case fatality rate in A Dictionary of Epidemiology. 4th edition; Oxford University Press, 2001; pp. 24 .

5. Köppen, W. The geographic system of climates. In: Handbuch der Klimatologie. Berlin: Borntraeger, 1936.

6. Chen, H.; Köppen, W. Climate classification as a diagnostic tool to quantify climate variation and change. http://hanschen.org/koppen, retrieved 2020.

7. John Hopkins University, Coronavirus Resource Center 2 2020. https://coronavirus.jhu.edu/ retrieved, 2020.

8. Carta, M.G.; Scano, A.; Minerba, L.; Romano, F.; Orrù, G. Does living in previously exposed malaria or warm areas is associated with a lower risk of severe COVID-19 infection in Italy? Biointerface Research in Applied Chemistry 2021, 11, 9744-9748, https://doi.org/10.33263/BRIAC112.97449748.

9. Carta, M.G.; Kalcev, G.; Scano, A.; Romano, F.; Cossu, G.; Littera, R.; Perra, A.; Deidda, S.; Firinu, D.; Del Giacco, S.; Campagna, M.; Chessa, L.; Zorcolo, L.; Restivo, A.; Orrù, G. Is the inversion in the trend of the Lethality of the COVID-19 in the two hemispheres due to the difference in seasons and weather?, Biointerface Research in Applied Chemistry 2021, 11,10429-10434.

10. Eurobserver $\mathbf{2 0 2 0}$ Coronavirus in Belarus: could Lukashenko's grip be shaken? https://euobserver.com/coronavirus/148048 Retrieved July 2020.

11. Petretto, D.R.; Masala, I.; Masala, C. School Closure and Children in the Outbreak of COVID-19. Clinical Practice \& Epidemiology in Mental Health 2020, 16, 189-191, https://doi.org/10.2174/1745017902016010189,

12. Kalcev, G.; Preti, A.; Orrù, G.; Carta, M.G. Mental Health and the COVID-19 Pandemic: A Call for Action. The Open Public Health Journal 2020, 13, 411-412, https://doi.org/10.2174/1874944502013010411.

13. Seligmann, H.; Iggui, S.; Rachdi, M.; Vuillerme, N. Inverted Covariate Effects for First versus Mutated Second Wave Covid-19: High Temperature Spread Biased for Young. Demongeot J.Biology 2020, 9, https://doi.org/10.3390/biology9080226. 
14. Kubota, Y.; Shiono, T.; Kusumoto, B.; Fujinuma, J. Multiple drivers of the COVID-19 spread: The roles of climate, international mobility, and region-specific conditions. PLoS One 2020, 15, https://doi.org/10.1371/journal.pone.0239385.

15. Cacciapaglia, G.; Cot, C.; Sannino, F. Second wave COVID-19 pandemics in Europe: a temporal playbook. Sci Rep 2020, 10, https://doi.org/10.1038/s41598-020-72611-5.

16. Zgueb, Y.; Preti, A.; Perra, A.; El-Astal, S.; Aviles-Gonzalez, CI.; Piras, M.; Testa, G.; Kirolov, I.; Tamburini, G.; Ouali, U.; Kalcev, G.; Romano, F.; Kovess, V.; Carta, MG. Staff Perception of Respect for Human Rights of Users and Organizational Well-being: A Study in Four Different Countries of the Mediterranean Area. Clin Pract Epidemiol Ment Health 2020, 30, 109-114, https://doi.org/10.2174/1745017902016010109.

17. Sancassiani, F.; Romano, F.; Preti, A. The Relevance of the Research on the Psychosocial Dimensions of Aging Is Really the Same in Europe and USA? Clinical Practice \& Epidemiology in Mental Health 2019, 15, 8-9, https://doi.org/10.2174/1745017901915010008.

18. Cacho, PM.; Hernández, JL.; López-Hoyos M.; Martínez-Taboada, VM. Can climatic factors explain the differences in COVID-19 incidence and severity across the Spanish regions?: An ecological study. Environ Health 2020, 13, 106, https://doi.org/10.1186/s12940-020-00660-4.

19. Zaitchi, BF.; Sweijd, N.; Shumake-Guillemot, J.; Morse, A.; Gordon, C.; Marty, A.; Trtanj, J.; Luterbacher, J.; Botai, J.; Behera, S.; Lu, Y.; Olwoch, J.; Takahashi, K.; Stowell, JD.; Rodó, X. A framework for research linking weather, climate and COVID-19. Nat Commun 2020, 12, 5730, https://doi.org/10.1038/s41467-020-19546-7.

20. Outcome Statement. Virtual Symposium on Climatological, Meteorological and Environmental (CME) Factors in the COVID-19 Pandemic. 4-6 August 2020. https://public.wmo.int/en/events/meetings/covid-19-symposium/outcomes(2020).

21. O'Dowd, K.; Nair, K.M.; Forouzandeh, P.; Mathew, S.; Grant, J.; Moran, R.; Bartlett, J.; Bird, J.; Pillai, S.C. Face Masks and Respirators in the Fight against the COVID-19 Pandemic: A Review of Current Materials, Advances and Future Perspectives, Materials (Basel) 2020, 13, 3363, https://doi.org/10.3390/ma13153363,

22. Meo, S.A.; Abukhalaf, A.A.; Alomar, A.A.; Sumaya, O.Y.; Sami, W.; Shafi, K.M.; Meo, A.S.; Usmani, J. A. Effect of heat and humidity on the incidence and mortality due to COVID-19 pandemic in European countries, J.Eur Rev Med Pharmacol Sci 2020, 24, 9216-9225, https://doi.org/10.26355/eurrev_202009_22874. 